\title{
Political Stability and Economic Growth in Nigeria
}

\author{
${ }^{1}$ Dennis Terpase Nomor, Ph.D and ${ }^{2}$ Paul Terhemba Iorember \\ ${ }^{1 \& 2}$ Department of Economics, Benue State University, Makurdi.
}

\begin{abstract}
The study empirically investigated the relationship between political stability and economic growth in Nigeria for the period 1999 to 2014 using the ARDL model approach. The result revealed a positive and significant relationship between political stability and economic growth both in the long run and in the short run. The study concludes that a stable political environment is an indispensable element for economic growth and therefore, the government of Nigeria should as a matter of necessity, identify the root causes of unstable political environment and try to mitigate its effects so as to ensure sustained growth in Nigeria.
\end{abstract}

Keywords: Political Stability, Economic Growth and ARDL Model.

\section{Introduction}

The importance of political stability to economic development of any country has become a topic of a continuous debate among economists, political scientists and politicians. Alesina, Ozler, Roubin and Swagel, (1996), argued that political stability and Economic growth are deeply interconnected. On the one hand, the uncertainty associated with an unstable political environment may reduce investment and the speed of economic development. On the other hand, poor economic performance may lead to government collapse and political unrest. On the role of political stability and economic performance in Bangladesh, Ahmed and Poluk (2103) argued that, political stability is expected to foster economic growth in the short run. Political stability ensure improvement in employment, protect the basic right of citizens, promote their culture and unity, provide basic infrastructure and services, electricity, water supply, healthcare and hence ensured increase in both local and foreign investment. Democracy fosters political stability and enhances economic growth relative to nondemocratic rule in a given country and political stability regardless of the extent of democracy, has significant effect on growth in developing countries (Abeyasinghe, 2004).

The year 1999 marked a watershed in the history of modern Nigeria, in that it ushered in what was expected to be 'enduring democracy'. Before then, the country had oscillated between civil and military rule, with the latter having longer periods. Since 1999, however, Nigeria has been enjoying uninterrupted democratic governance which presupposes political stability yet the growth of the economy seems illutionary. It is this reality that informed this study given the fact that democratic governance should ordinarily, among other things, usher in societal development, inclusion and participation of citizens in governance; accountability and transparency on the part of government officials as well as a stable political environment which attracts investment (local and foreign) that leads to increase growth of the economy. Also, studies on the impact of political stability on economic performance in Nigeria are scarce in literature, even the few available ones in literature are more of content analysis (i.e. they are analyzed qualitatively). This study therefore differ from existing studies in that, it quantitatively investigated the relationship between political stability and economic growth in Nigeria using time series data over the period between 1999 and 2014 which is considered most recent in terms of data availability.

\section{Conceptual Framework}

\section{Literature Review}

According to Encyclopedia Britannica, Political stability is the durability and integrity of a current government regime. This is determined based on the amount of violence and terrorism expressed in the nation and by citizens associated with the state. A stable society is one that is satisfied with the ruling party and system of operations and is not interested in revolutionary or despotic ideas. A stable political scene is one where the ruling government is favored by the population and does not experience strong indicators of social unrest. While there are problems within any nation, and times of war or hardship are common, a stable political system is one that can withstand these occurrences without major societal upheaval and ongoing endurance of these circumstances.

According to Sottilotta, (2013), the concept of political stability is a very controversial concept. Sottilitta argued that; a first broad definition refers to the absence of domestic civil conflict and widespread violence. In this sense, a country can be considered rid of instability when no systematic attacks on persons or property take place within its boundaries. Secondly, classic interpretation equates stability with government longevity. Thirdly, political stability draws on the lack of structural change, that is, the absence of internally or 
externally induced change in the basic configuration of a polity. In the same way, Paldam (2016) defined political stability to cover four dimensions; stable government, stable political system, internal law and external stability. Paldam argued that, these four dimensions are sufficient for the explanation of political stability.

The International Consulting Firm Eurasia Group cited in Sottilotta, (2013), defined political stability as the capacity of a country's political system to withstand internal or external shocks. In this sense, a broad operational definition of political stability should take concepts and indicators into account such as human development (as measured by the UN Human Development Index); inequality (Gini index); political legitimacy (i.e. the more or less widespread support for the government, be it democratic or non-democratic); constraints on regime responsiveness (i.e. the economic constraints that governments encounter in meeting the requests of their citizens as expressed, for instance, by the total stock of a country's public debt); and regional/international integration (meaning, for instance, membership in international and regional organizations or the ratio of total foreign trade over GDP).

According to Kindleberger in Jhingan (2007), Economic growth as more output, while economic development implies both more output and changes in the technical and institutional arrangement by which it is produced and distributed. Friedman in his fashion defines growth as an expansion of the system in one or more dimension without a change in its structure, and development as an innovative process leading to the structural transformation of a social system. According to Iyoha (1999), economic growth is defined as a persistent rise in the national income over a range of time of not less than five years. In economic growth theory, growth is usually calculated in real terms, that is, inflation-adjusted terms, in order to obviate the distorting effect of inflation hence, the use of real gross domestic product in most growth literature.

According to Essien (2001), Economic growth is simply the percentage or proportionate increase in real income during a given period, usually a year. It is the rate at which gross domestic product (GDP) is duringpositive growth or decreasing-negative. Economic growth occurs when there is a positive increase in economic variables, real or nominal, normally persisting over successive period. Akin (1998) assert that, economic growth has two tentacles, namely, extensive and intensive economic growth. Extensive economic growth is present when output of a nation, as measured by real GNP is expanding regardless of whether output per capita increases; while intensive economic growth is a situation in which there exist an increase in output per person or expansion in the availability of goods and services per capita. Thus, a nation may experience extensive economic growth even though the output per-capital is not rising.

According to Wikipedia the free encyclopedia (2011) Economic growth is the increase in the market value of the goods and services produced by an economy over time. It is conventionally measured as the percent rate of increase in real gross domestic product, or real GDP. Of more importance is the growth of the ratio of GDP to population (GDP per capita), which is also called per capita income. An increase in per capita income is referred to as intensive growth. GDP growth caused only by increases in population or territory is called extensive growth. Growth is usually calculated in real terms - i.e., inflation-adjusted terms - to eliminate the distorting effect of inflation on the price of goods produced. In economics, "economic growth" or "economic growth theory" typically refers to growth of potential output, i.e., production at "full employment".

\section{Theoretical and Empirical Framework}

Many scholars have made attempts to theoretically establish the relationship between political stability and economic growth. According to Arthur, (1987), most social scientists simply assume that stability has instrumental economic value. They tend to believe it is a necessary condition for growth and prosperity, but rarely feel a need to test this proposition. The reason is obvious: people are encouraged to invest and trade when they are confident in the future, and few things seem more likely to undermine business and consumer confidence than the prospect of political unrest and sudden changes in the economic "rules of the game." Using the language of systems theory, Holt and Turner argued that, "One of the prerequisite of economic growth, which has been discussed in the economic literature from the time of the classical economists, is that government must maintain law, order, and a modicum of security".

Mancur Olson's theory of stability and growth cited in Arthur, (1987) explicitly claimed that, a complex relationship exists with economic growth. War, revolution, and other destabilizing events obviously disrupt economic activities in the short term and set the stage for more rapid growth in the medium term. Over the long term, however the theory asserts that political stability can be economically dysfunctional and cause growth to decelerate. Political stability has these economic effects because of the self-seeking activity of interest groups or "distributional coalitions." Drawing from his earlier work on the individualistic basis of group behavior, Olson asserts that "stable societies with unchanged boundaries tend to accumulate more collusions and organizations for collective action over time. His major conclusion is that these "distributional coalitions slow down a society's capacity to adopt new technologies and to reallocate resources in response to changing economic conditions, and thereby reduce the rate of economic growth." Olson is careful to avoid suggesting, however, that chronic political instability is beneficial for economic growth, despite the fact that it might keep 
interest groups perpetually off balance. It is worth quoting his reasoning at some length. Olson's theory implies that political stability and instability are dichotomous: instability must reach a threshold to disrupt distributional coalitions. Lesser degrees of instability may not trigger this effect at all. The discontinuous character of stability suggests a fourfold typology of political systems. Each type is expected to have a characteristic growth pattern. (1) The Chronically Unstable states should exhibit persistently slow growth. (2) The Consistently Stable ones should grow relatively quickly but show a declining trend over time. (3) The Stabilizing political systems that are settling into a new pattern of political order should undergo a spurt in growth rate. (4) Finally, there are regimes that are becoming less stable. Olson does not make an explicit prediction about these destabilizing systems, but the inference is that their growth rates would drop sharply.

Many studies have established the relationship between political stability and economic growth in various ways however most of these studies link political instability rather than stability with economic growth. Some of these studies include studies by Barro (1990), Devereux and Wen, (1996) Alesina and Perroti (1996), Edward and Tabellini (1991) and Bildirici (2004). For instance, using cross sectional analysis Barro (1990) found that economic growth is affected negatively by political instability as property rights are hardly implemented in unstable political situation. Devereux and Wen (1996) argued that unstable political situation discourages private investments which in turn affects economy negatively. Alesina and Perroti (1996) used three different variables to proxy for the political instability and found it causing a decrease in economic growth.

According to Edward (1998), there exists a negative relationship between political instability and productivity growth for a panel of 93 countries for the period of 1960-1990, though the relation was relatively weak. Taking a panel date of four countries, Bildirici (2004) examined the relationship between political instability and economic growth. The study found out a negative relationship between the variables under study,

Drazen (2000) identified two reasons for which political instability affects economic performance. Firstly, it creates uncertainty about future return from the investment of firms and private agents, which inhibits the society as a whole to accumulate physical capital. Again, there is a direct effect of political instability on productivity as it distorts the functions of the market. Lower economic growth due to lower human capital accumulation owing to endemic political instability is the finding of Maloney (2002) for his study of Latin American countries.Yunis et. al (2008) investigated the effects of various political instability factors on economic growth for selected Asian countries during 1990-2005. The study found close relationship between political stability and economic growth and the results showed that the role of political stability is more important than economic freedom. Aisen and Veiga (2010) used GMM estimator for linear dynamic panel data models on a sample of 169 countries, and 5-year periods from 1960 to 2004 to investigate the link between political instability and economic growth, and found that lower growth is associated with higher degree of political instability.

Country specific studies include the studies by Munoz (2009), Astteriou and Price (2001) and Campus and Karanasos (2007). Munoz (2009) used ARDL framework to investigate the link between political instability and economic growth for Venezuela for the period of 1983-2000. He found that political instability affects growth negatively but not through the channel of investment. Astteriou and Price's study was to test the influence of political instability on UK economic growth for 1961-1997 using GARCH-M model. Their study revealed a negative effect on growth and positive effect on growth. Also, Campos and Karanasos (2007) used power ARCH framework with yearly data for Argentina for the period 1896-2000 and came up with the conclusion that both the informal political stability (assassinations and strikes) and the formal political stability (constitutional and legislative changes) have direct negative effect on economic performance. The effect of formal instability was stronger in the long run while the effect of informal instability was stronger in the short run in their study. Astteriou and Siriopoulos (2000) examined the relationship empirically for Greece and found strong negative association. Abeyasinghe, (2004) reported that, political stability regardless of the level of democracy has the greatest effects on the country's economic growth.

Few studies however found a negative relationship between political stability and economic growth. Goldsmith (1987) found that for LDCs, political stability negatively affected economic growth. However, it was only to a little extent._Ahmed and Pulok (2013) investigated the direct effect of political stability on the economic performance of Bangladesh for the period of 1984-2009. Their study found out that, political stability has negative effect on economic performance in long term while the short run effect is positive.

\section{Methodology And Material}

This section deals with the development of the model, the methodology adopted and the definition and sources of data for the study.

\section{Model Development}

Political instability as opposed to political stability is associated with greater uncertainty regarding future economic policy, it is likely to adversely affect investment and, consequently, physical capital accumulation. In fact, several studies have identified a negative relationship between political instability and 
investment (Alesina and Perotti, 1996; Mauro, 1985; Perotti, 1996). It is also possible that political instability adversely affects productivity. By increasing uncertainty about the future, it may lead to less efficient resource allocation. Similarly, human capital accumulation may also be adversely affected by political instability because uncertainty about the future may induce people to invest less in education as it is the case in Nigeria's North East. Additionally, it may reduce research and development efforts by firms and governments, leading to slower technological progress. Violence, civil unrest, strikes and insurgency can also interfere with the normal operation of firms and markets reduce hours worked, and even lead to the destruction of some installed productive capacity. Thus, we hypothesized that while political stability is associated with economic growth; political instability on the other hand is associated with lower productivity growth.

To uncover this relationship, we adopted an augmented Solow production function (Solow, 1956) that makes output a function of physical capital, labour, human capital and technology (Mankiw, Romer \& Weil, 1992). In a Cobb-Douglas production function framework, this is specified as:

$$
Y=A K^{\alpha} L^{\beta} H^{\gamma}
$$

Where $Y$ is total output, $K$ is physical capital, $L$ is labour, $H$ is human capital stock, and $A$ is technology. According to Mankiw et al. (1992), $A=a+\varepsilon$ in which technology is broken into constant $a$ and country specific deviation $\varepsilon$. With this, Mankiw et al. (1992) successfully dump the effect of technology into the regression error term.

Taking logarithm and differentiating equation (1) becomes:

$$
Y=\alpha+\phi K+\beta L+\gamma H+\varepsilon
$$

By modifying the augmented Solow model in equation 2 in line with the argument by North (1990) which states that institutions in a country determine its long-run economic performance. Here, institutions refer to political stability, quality of government, independent judicial system, political rights, property rights etc. Political stability can directly affect the growth through affecting total factor productivity of the country. It is assumed that political stability affects economic growth by enhancing or reducing total factor productivity (TFP). Hence, the model for the study becomes;

$$
Y=\alpha+\phi K+\beta L+\Phi P S I+\Psi G E+\Omega R C+\varepsilon
$$

Where PSI, GE and $R C$ stand for political stability index,government effectiveness and regime changes respectively. While $\phi$ and $\beta$ are the estimated coefficients, $\Phi, \Psi$ and $\Omega$ are the total factor productivity terms and $\alpha$ is the intercept term.

\section{Methodology}

The study made use of the autoregressive Distributed Lag Model in the estimation of the relationship between political instability and economic growth in Nigeria.

The ARDL Bounds cointegration test was first developed by Pesaran and Shin (1999) and later extended by Pesaran et al (2001). It has been used extensively in the literature for three reasons. Firstly, unlike the Johansen-Juselius cointegration test, it allows for cointegration testing even when all variables are integrated of order I $(0)$ or $\mathrm{I}(1)$, or a mix of the two. Secondly it is not sensitive to the values of error parameters hence making it ideal for small sample estimation. Lastly, the ARDL Bounds approach is proven to provide unbiased long run estimates with valid t-statistics even when some of the cointegrated variables are endogenous (Amusa et al, 2009). The above features makes the ARDL Bounds approach to cointegration ideal for use in this paper particularly since the data sample is small and the variables are a mix of $\mathrm{I}(0)$ and $\mathrm{I}(1)$.

Therefore, an ARDL representation of equation (2) can be specified in equations as follows;

$$
\Delta Y=\alpha \sum_{i=1}^{p} \delta \Delta Y_{t-1}+\sum_{i=1}^{p} \phi \Delta K_{t-1}+\sum_{i=1}^{p} \beta \Delta L_{t-1}+\sum_{t=1}^{p} \Theta \Delta P S I_{t-1}+\sum_{t=1}^{p} \Psi \Delta G E_{t-1}+\sum_{t=1}^{p} \Omega \Delta R C_{t-1}+\lambda E C M+\varepsilon^{-----}
$$

4

Where $E C M$ is the residuals obtained from equation 3 (i.e. the error correction term). $\delta$ is the coefficient of the lagged total output and $\lambda$ is the speed of adjustment parameter that is expected to be negative and statistically significant to further confirm the existence of a cointegrating relationship.

\section{Data definition and sources}

Data used in this paper are annual data on the Nigerian economy between 1999 and 2014. The selection of this period is related to the availability of data and also involves the era of longest uninterrupted democratic regimes. The data has been divided into economic and political categories.

Economic growth measures annual percentage growth rate of GDP at market prices based on constant local currency. In Nigeria and other countries, economic growth is calculated as the percent change in the GDP from 
one year to the next. It measures whether production has increased or decreased, and by how much. It is sourced from the CBN statistical bulletin.

Capital Investment also refers to as Gross capital formation (formerly gross domestic investment) consists of outlays on additions to the fixed assets of the economy plus net changes in the level of inventories (World Bank, 2010). In Nigeria and other countries, capital investment is calculated as the purchases of new plant and equipment by firms, as percent of GDP. A high number is good for long-term economic growth as current investment leads to greater future production. It is sourced from the World Bank's World Development Indicators (WDI).

Unemployment rate in Nigeria and other countries is defined as the number of unemployed people as percent of the labor force. The labor force includes the people who are either employed or unemployed (i.e those who don't have jobs but are actively looking for one). Unemployment Rate according to the World Bank (2010) is the share of the labor force that is without work but available for and seeking employment. It is sourced from the World Bank's GlobalEconomy.com.

Index of Political Stability (-2.5 weak; 2.5 strong) and Absence of Violence/Terrorism measures perceptions of the likelihood that the government of Nigeria will be destabilized or overthrown by unconstitutional or violent means, including politically-motivated violence and terrorism. The index is an average of several other indexes from the Economist Intelligence Unit, the World Economic Forum, and the Political Risk Services, among others. It is sourced from the World Bank's GlobalEconomy.com.

Index of Government Effectiveness (-2.5 weak; 2.5 strong) in Nigeria captures perceptions of the quality of public services, the quality of the civil service and the degree of its independence from political pressures, the quality of policy formulation and implementation, and the credibility of the government's commitment to such policies in Nigeria. It is sourced from the World Bank's GlobalEconomy.com.

Regime Changes is a dummy variable used as a measure of changes in government over the period of the study. The variable takes zero (0) for any change of government at the center and one (1) if otherwise. It is constructed by the author.

\section{Estimation and Discussion of Results}

Although the bounds testing procedure does not require the pre-testing of the variables included in the model for unit roots owing to its suitability irrespective of whether the regressors in the model are purely $I(0)$, purely $I(1)$ or mutually cointegrated, the application of unit root tests in the ARDL procedure might still be necessary in order to ensure that the regressand is integrated of order one and none of the variables is integrated of order 2 or beyond because the computed F-statistics provided by Pesaran et al. (2001) are valid for only variables that are $I(0)$ or $I(1)$. The first step in the estimation of time series data set is to verify the existence or otherwise of unit root. This is particularly important because, if an OLS regression is estimated with nonstationary data and residuals, the regression estimates are most likely spurious. To do this, the logged series were first plotted against time to observe their properties as shown in Figure 1.
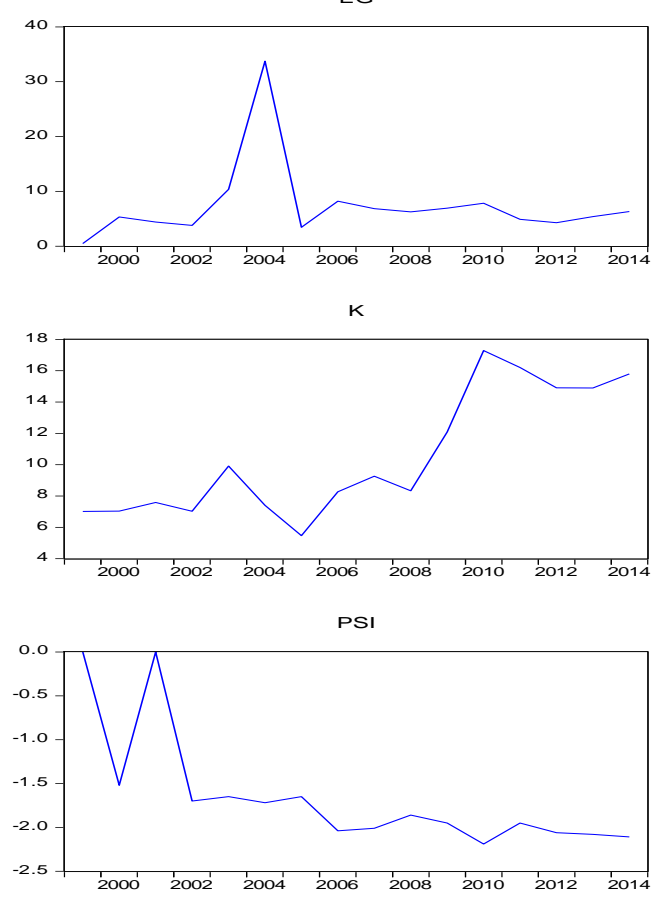

GE
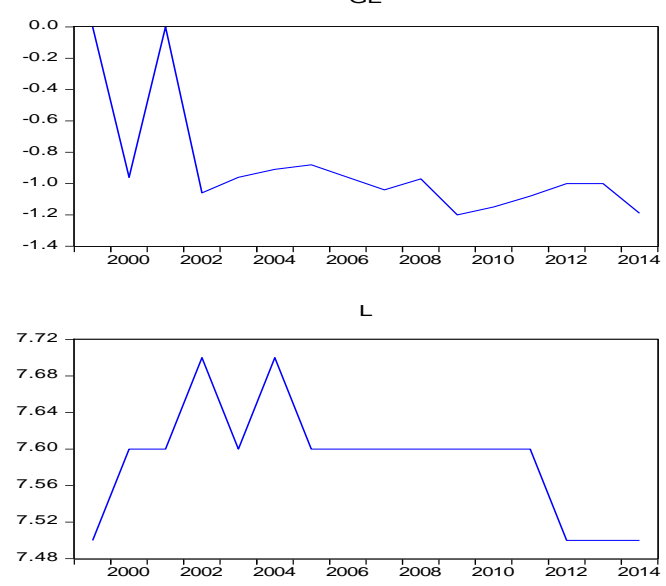

$\mathrm{RC}$

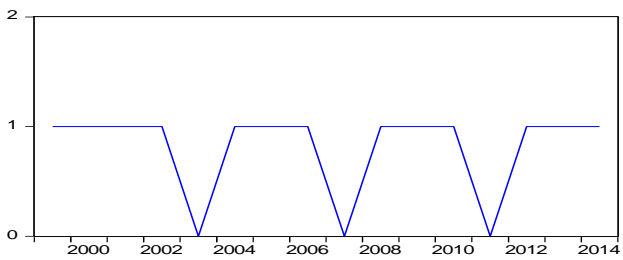

Figure 1: Line Plot of the Variables used for the study 
The trends in Figure 1 revealed wide fluctuations likely to produce positive autocorrelation which makes a series non stationary. Therefore, it is important to test for the stationarity or otherwise of the series and correct for the non-stationary series. One way of correcting the non stationary series into a stationary series is through the method of differencing. This study uses the Augmented Dickey Fuller Test (ADF) stationarity test to verify the stationarity or otherwise of the original and the differenced series, based on $5 \%$ significance level. The result is presented in the table below:

Table 1: Table 1 ADF Unit-Root Test Result for the Series

\begin{tabular}{|l|l|l|l|}
\hline Series & $\begin{array}{l}\text { ADF T-Statistic } \\
\text { [evel }\end{array}$ & $\begin{array}{l}\text { ADF T-Statistic } \\
@ \\
\mathbf{1}^{\text {st }} \text { Difference }\end{array}$ & Decision \\
\hline EG & $-3.6936(-3.0810)$ & - & Stationary @ I (0) \\
\hline K & $-0.8017(-3.0810)$ & $-3.7695(-3.1199)^{*}$ & Stationary @ I $(1)$ \\
\hline L & $-1.0183(-3.1199)$ & $-6.8739(-3.0889)^{*}$ & Stationary @ I(1) \\
\hline PSI & $-8.0127(-3.1199)^{*}$ & - & Stationary @ I(0) \\
\hline GE & $-4.7091(-3.0810)^{*}$ & - & Stationary @ I $(0)$ \\
\hline RC & $-6.2450(-3.1199)^{*}$ & - & Stationary @ I $(0)$ \\
\hline
\end{tabular}

Source: Author's computation from Eviews 9.0

Note: Values in parenthesis are the critical values at $5 \%$ level of significance

Table 1 reveals a mixed order of integration (i.e I(0) and I(1)) among the variables.. EG, PSI, GE and RC variables are integrated of order zero $(\mathrm{I}(0))$ while $\mathrm{K}$ and $\mathrm{L}$ variables are integrated of order one $(\mathrm{I}(1))$ ). Therefore, since the variables under the study are not integrated of the same order and none of the variables is stationary at $\mathrm{I}(2)$, the application of ARDL is justified and hence the use of bounds approach to cointegration over other conventional approaches that require the variables to be integrated of the same order.

\section{ARDL Bounds Test for Cointegration}

Given a relatively small sample size (13) and the use of annual data, a lag length of 1 is used in the bounds test, Pesaran and Shin (1999). The results of the bound test are given in table 2.0. The critical values used in this paper are extracted from the ARDL results using Microfit software.

Table 2: ARDL Bounds Test for Cointegration

\begin{tabular}{|l|l|l|l|}
\hline F-statistic & Critical Values & $\begin{array}{l}\text { Lower bound } \\
\text { value }\end{array}$ & Upper bound value \\
\hline & $1 \%$ & 3.7421 & 5.0614 \\
\hline 5.21 & $5 \%$ & 2.6051 & 3.9403 \\
\hline & $10 \%$ & 2.1077 & 3.2851 \\
\hline
\end{tabular}

Excepts from MicroFit 5.0

Note: Critical Values are cited from PESARAN et al. (2001), Table CI (iii), Case 111: Unrestricted intercept and no trend for $K=5$.

The computed F-statistics; $F_{E G}(K, L, P S I, G E, R C)$ as shown in Table 2 is $=5.21$. This value is above the upper bounds of the critical value of 4.01 at $5 \%$ level of significance. This implies that there is cointegration (long run relationship) between economic growth, capital investment, unemployment rates, index of political stability, Index of Government Effectiveness, and regime change. Therefore, the null hypothesis of no cointegration between the variables is rejected and the alternative hypothesis is accepted implying that, a long run relationship exists among the variables of the study.

\section{Estimated Long Run Relationship}

The existence of a long run relationship among the variables of the study suggests the estimation of long run coefficients and short run dynamic parameters. The estimation of the ARDL model is based on the Schwarz Bayesian Criterion (SBC). The long-run results and the diagnostic test statistics of the estimated model are presented in the table below;

Table 3: Estimated Long Run Relationship using ARDL Approach

\begin{tabular}{|l|l|l|l|l|}
\hline Dependent variable: EG & \multicolumn{5}{l|}{} \\
\hline Regressor & Coefficient & Standard Error & T-Ratio & Prob \\
\hline K & 5.3645 & 0.8745 & 6.1344 & 0.000 \\
\hline L & -2.0411 & 0.4452 & -4.5847 & 0.001 \\
\hline PSI & 0.2541 & 0.0354 & 7.1780 & 0.000 \\
\hline GE & -5.6702 & 0.6354 & -8.9238 & 0.000 \\
\hline RC & -0.1412 & 0.1052 & -1.3422 & 0.245 \\
\hline INTP & 4.3654 & 0.2411 & 18.106 & 0.000 \\
\hline
\end{tabular}

Excepts from MicroFit 5.0

ARDL $(0,1,1,1,1,0)$ selected based on Schwarz Bayesian Criterion 
The result of the estimated coefficients of the long run relationship in Table 3 indicates that capital investment $(K)$ and political stability index have positive and significant effect on economic growth at $5 \%$ probability level. The estimated coefficient of capital investment $(K)$ is 5.3645 and that of political stability is 0.2541 . This implies that a unit change in capital investment and political stability will affect economic growth positively by 5.3645 and 0.2541 respectively. On the other hand, unemployment rate $(L)$, government effectiveness index $(G E)$ and regime change $(R C)$ have negative effect on economic growth in Nigeria. A unit change in each will affect economic growth by $2.0411,5.6702$ and 0.1412 respectively. All the variables except regime change (RC) are significant at $5 \%$ probability level.

The result of the short run relationship is presented in Table 4 below.

Table 4: Table 4: Estimated Short Run Relationship using ARDL Approach

\begin{tabular}{|c|c|c|c|}
\hline \multicolumn{4}{|c|}{ Dependent variable is dEG } \\
\hline Regressor & Coefficient & Standard Error & T-Ratio [Prob] \\
\hline $\mathrm{dK}$ & 2.1640 & 0.8291 & $2.6104 \quad[.028]$ \\
\hline $\mathrm{dL}$ & -4.4842 & 0.6454 & $-6.9479[.000]$ \\
\hline dPSI & 2.5653 & 0.3354 & $7.6574 \quad[.000]$ \\
\hline $\mathrm{dGE}$ & -10.095 & 0.6354 & $-15.888 \quad[.000]$ \\
\hline $\mathrm{dRC}$ & -0.2434 & 0.1052 & $2.3137 \quad[.031]$ \\
\hline $\operatorname{ECM}(-1)$ & -0.7851 & 0.2144 & $-3.6618 \quad[.011]$ \\
\hline R-Squared & 0.88940 & R-Bar-Squared & 0.74194 \\
\hline S.E. of Regression & 5.37650 & F-Stat. $\quad F(5,9)$ & $9.6500[.002]$ \\
\hline DW-statistic & 1.79021 & $\begin{array}{l}\text { Schwarz Bayesian } \\
\text { Criterion }\end{array}$ & -51.8288 \\
\hline
\end{tabular}

Excepts from MicroFit 5.0

The results of the short run dynamic coefficients associated with the long run relationships obtained from the error correction model given in Table 4. The signs of the short run dynamic interactions are consistent with that of the long run relationship. The estimated error correction coefficient of -0.7851 with a probability value of 0.002 is highly significant, has the correct sign, and imply a fairly high speed of adjustment to equilibrium after a shock. Approximately $78.5 \%$ of disequilibria from the previous year's shock converge back to the long run equilibrium in the current year. All the variables of the study were found to be significant at $5 \%$ probability level.

\section{Diagnostic Tests}

The outcome of the Lagrange multiplier test of residual serial correlation, Ramsey's RESET test, Jarque Bera normality test and Heteroscedasticity test as presented in Table 5 indicates the model passed all the tests and this implies that it has a correct functional form, its residuals are serially uncorrelated, normally distributed and homoscedastic.

Table 5: ARDL Model Diagnostic Test

\begin{tabular}{|l|l|l|}
\hline \multicolumn{2}{|l|}{ LM Test Statistics } & Prob. \\
\hline A: & $\chi^{2}(1)=0.8323$ & 0.1422 \\
\hline B: & $\chi^{2}(1)=1.4152$ & 0.6337 \\
\hline C: & $\chi^{2}(1)=0.6496$ & 0.9852 \\
\hline D: & $\chi^{2}(1)=3.4512$ & 0.4851 \\
\hline
\end{tabular}

Excepts from MicroFit 5.0

Note: A:Lagrange multiplier test of residual serial correlation

B:Ramsey's RESET test using the square of the fitted values

$C:$ Based on a test of skewness and kurtosis of residuals

$D: B a s e d$ on the regression of squared residuals on squared fitted values

\section{Stability Test of the Model}

The study made use of the Cumulative Sum of Recursive Residuals (CUSUM) and Cumulative Sum Squares of Recursive Residuals (CUSUMSQ) in testing for the stability of the parameters of the model. The CUSUM and CUSUMQ plots from a recursive estimation of the model are shown in Figures 2 and 3, respectively. This indicates stability in the coefficients over the sample period as the plot of the CUSUM and CUSUMSQ statistic fall inside the critical bands of the 5\% confidence interval of parameter stability. 


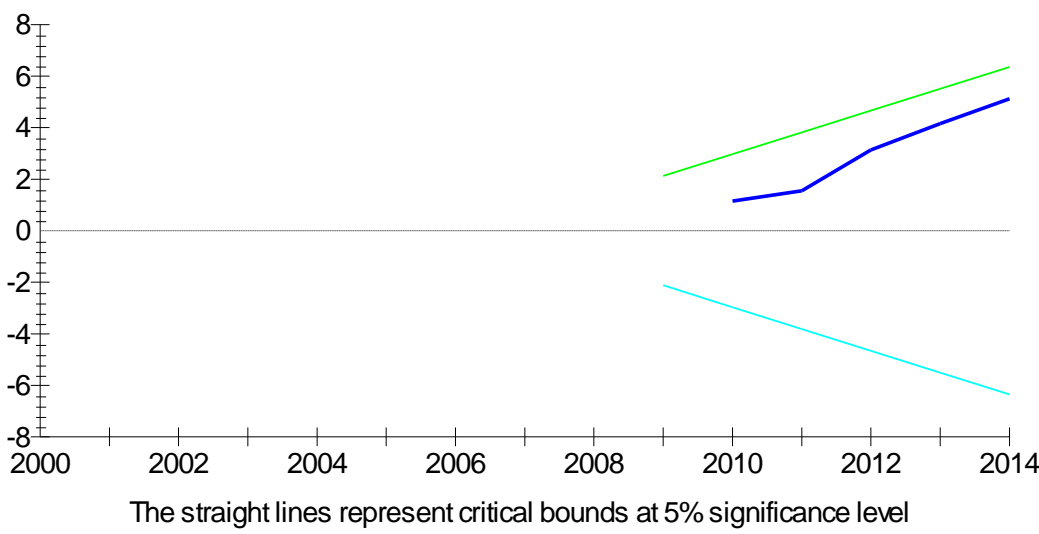

Figure 2: Plot of Cumulative Sum of Recursive Residuals (CUSUM)

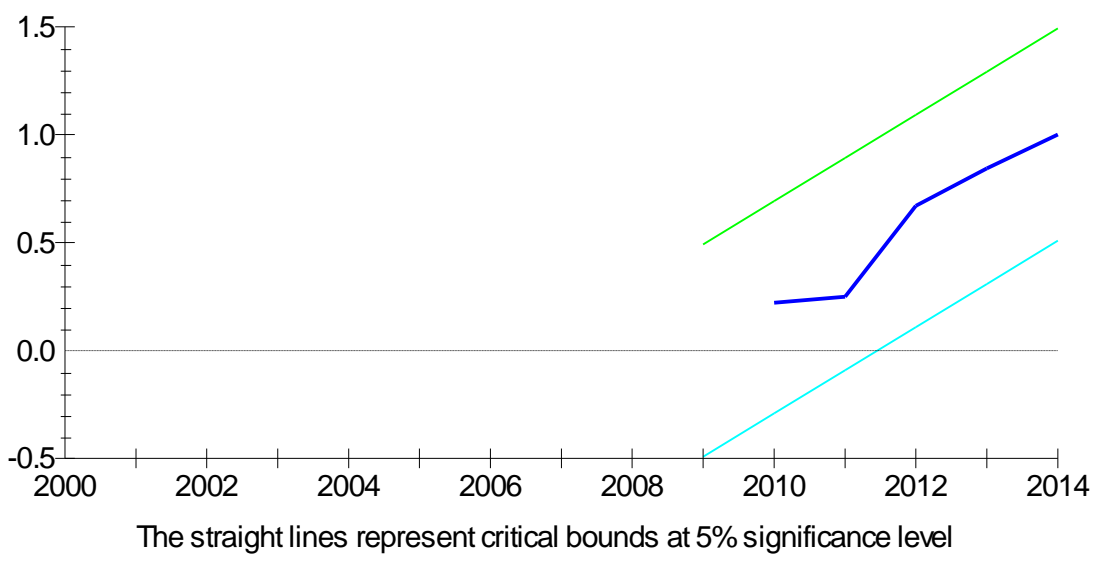

Figure 3: Plot of Cumulative Sum Squares of Recursive Residuals (CUSUMSQ)

It is evident from the plots of both the CUSUM and the CUSUMSQ, that it can be seen that both the statistics are within the critical bounds region; suggesting the stability of the parameters of the study.

\section{Conclusion And Policy Recommendation}

The study was carried out with the main aim to econometrically analyse the relationship between political stability and economic growth in Nigeria. Using time series data on GDP at market price, gross capital formation, unemployment rate, index of political stability, index of government effectiveness and regime; the bound testing approach to cointegration was employed. The result revealed a positive and significant relationship between political stability and economic growth both in the long run and short run. The study concludes that a stable political environment is an indispensable element for economic growth and therefore, the government of Nigeria should as a matter of necessity, identify the root causes of unstable political environment and try to mitigate its effects so as to ensure sustained economic growth in Nigeria.

\section{Reference}

[1]. Abeyasinghe, R. (2004). Democracy, Political Stability and Developing country Growth: Theory and Evidence. Illinois Wesleyan University. Honours Projects. Paper 17

[2]. Ahmed, M. Uddin and Pulok, M. H. (2013) The Role of Political Stability on Economic Performance: The Case of Bangladesh. Journal of Economic Cooperation and Development. Vol. 34 No. 3: pp 61-100.

[3]. Aisen A. and Veiga F.J. (2010),"How Does Political Instability Affect Economic Growth?",Central Bank of Chile Working Papers, No 568 .

[4]. Akin, T. (1998). External Debt and Debt Services Ratios. Journal of Economics and Finance. Vol. 3: pp 467-690.

[5]. Alesina, A. and Perotti, R. (1996). Income Distribution, Political Instability, and Investment. European Economic Review Vol. 40 : pp 1203- 1228 . 
[6]. Alesina, A., Ozler, S., Roubini, N. and Swagel, P. (1996). "Political Instability and Economic Growth." Journal of Economic Growth. Vol. 1: pp 189-211.

[7]. Amusa, H., Amusa, K. and Mabugu, R., (2009). Aggregate demand for Electricity in South Africa: An analysis using the bounds testing approach to cointegration. Energy Policy. Vol.37 No.10: pp 4167-4175.

[8]. Arthur, A. G. (1987) Does Political Stability Hinder Economic Development? Mancur Olson's Theory and the Third World . Comparative Politics. Vol. 19, No. 4: pp 471-480

[9]. Asteriou, D. and Price, S.(2001), "Political Instability and Economic Growth: UK Time Series Evidence", Scottish Journal of Political Economy. Vol. 48: pp 383-399.

[10]. Asteriou, D. and Siriopoulos C. (2000), "The Role of Political Instability in Stock Market Development and Economic Growth: The Case of Greece", Economic Notes by Banca Monte dei Paschi di Siena SpA, Vol. 29, No. 3-2000: pp. 355-374.

[11]. Barro, R. J. (1990). Government Spending in a Simple Model of Exogenous Growth. Journal of Political Economy. Vol. 98: pp 103-125.

[12]. Bildirici, M. (2004). Political Instability and Growth: An Econometric Analysis Of Turkey, Mexico, Argentina and Brasil. 19852004. Applied Econometrics and International Development. Vol. 4. No 4: pp 5-26

[13]. Campos N. and Karanasos M. (2007), "Growth, Volatility and Political Instability: Non-Linear Time-Series Evidence for Argentina, 1896-2000”, William Davidson Institute Working Paper Number 891.

[14]. Devereux, M. and J. Wen (1996), "Political Uncertainty, Capital Taxation and Growth", Mimeo, University of British Columbia, Vancouver, Canada.

[15]. Drazen, A. (2000). Political Economy in Macroeconomics. New Jersey: Princeton University Press.

[16]. Edwards, S. and G. Tabellini. (1991), "Political Instability, Political Weakness and Infation: An Empirical Analysis", NBER Working Paper 3721.

[17]. Essien, A. (2001) "Trade and Nigerian Economy" First Bank of Nigeria Quarterly Review, Vol.12.

[18]. Goldsmith A.A. (1987), "Does Political Stability Hinder Economic Development? Mancur Olson's Theory and the Third World", Comparative Politics, Vol. 19, No. 4: pp 471-480.

[19]. Iyoha, M.A. (1999). "External Debt and Economic Growth in sub-Saharan African Countries: An econometric study." Research Paper 90, AERC Research Paper Series. Nairobi, Kenya: African Economic Research Consortium.

[20]. Jhingan, M. L. (2007). The Economics of Development and Planning. Delhi: Vrinda Publications.

[21]. Maloney, W. (2002), "Missed Opportunities: Innovation and Resource-Based Growth in Latin America", Economía. Vol. 3 No. 1: pp 111-167.

[22]. Mankiw, N. G., Romer, D. and Weil, D. (1992), “A contribution to the empirics of economic growth.” Quarterly Journal of Economics. Vol. 107: pp 407-437.

[23]. Mauro, P. (1995). “Corruption and growth.” Quarterly Journal of Economics Vol.110 No. 3, pp. 681-712.

[24]. Munoz R.(2009), "Political Instability and Economic Growth: the case of Venezuela (1983 - 2000)", Political Uncertainty and Macroeconomic Outcomes: Theoretical and Empirical Essays, University of Essex, PhD Thesis

[25]. Paldam, S. (2016). Does Economic Growth Lead to Political Stability?

[26]. Perotti, R. (1996). "Growth, income distribution, and democracy: what the data say." Journal of Economic Growth. Vol. 1: 149-187

[27]. Pesaran, H. H. and Shin, Y. (1999). "Generalized Impulse Response Analysis in Linear Multivariate Models". Economics Letters, 58: $17-29$.

[28]. Pesaran, M.H., Y. Shin and R. Smith (2001): Bounds Testing Approaches to the Analysis of level Relationships. : Journal of Applied Econometrics. Vol. 16 No. 3: pp 289-326.

[29]. Sottilitta, C. E. (2013). Political Stability in Authoritarian Regimes: Lessons from the Arab Uprisings. A Working Paper 13.

[30]. Yunis M, Lin, Y. Sharahili, S. Selvarathinam (2008), "Political Stability and Economic Growth in Asia", American Journal of Applied Sciences. Vol. 5 No. 3: pp 203-208.

[31]. World Bank (2010). Development Report. World Bank, Washington. D. C. 